\title{
LEMBAR METODOLOGI
}

\section{ETIKA PENULISAN KARYA ILMIAH KEPERAWATAN}

\author{
Hanny Handiyani *
}

\begin{abstract}
Abstrak
Hakekat suatu karya/ karangan ilmiah adalah suatu bacaan yang menyajikan fakta dan kebenaran secara obyektif serta disajikan sesuai dengan kaidah penulisan ilmiah. Hal ini menuntut kejujuran penulis dalam menampilkan informasi tersebut secara efektif sehingga pembaca mendapatkan pemahaman yang sesuai dengan maksud penulis dan fakta yang disampaikan. Semakin banyak karya ilmiah keperawatan yang ditemukan menunjukkan telah semakin tingginya kesadaran ilmuwan keperawatan yang menunjukkan eksistensinya melalui karya ilmiah baik melalui kesadaran sendiri maupun karena kondisi adanya tugas menulis yang wajib dilakukannya. Perkembangan ini seyogyanya diiringi dengan kesadaran penulis menerapkan aspek etika penulisan karya ilmiahnya. Bila tidak, maka akan rusaklah perkembangan ilmu pengetahuan itu. Berbagai aspek etika penulisan ini akan diuraikan pada tulisan berikut ini.
\end{abstract}

Kata kunci: etika, karya/ karangan ilmiah

\section{Abstract}

A scientific writing is a form of formal writing that provide facts and truth objectively and scientifically. It requires the writer honesty to present the information effectively, so that the reader will grasp the meaning of the article. Nowadays, large number of nursing scientific writing is produced by nursing scholars in Indonesia. However, this indicator should be followed by the application of ethical aspect in the writing. This article will discuss the ethical aspect in writing scientific article.

Key word: ethic, scientific writing

\section{PENDAHULUAN}

Ilmu pengetahuan tidak dapat berkembang tanpa adanya bukti tertulis yang menggambarkan sejauh mana suatu bidang ilmu telah dipelajari melalui penelitian maupun didiskusikan dalam suatu pembahasan tinjauan kepustakaan. Kejujuran penulis menjadi hal yang sangat penting dalam menyajikan kebenaran ilmiah itu secara obyektif dalam bentuk karya tulis ilmiah. Karya ilmiah berbentuk karangan itu dapat dituangkan penulis dalam bentuk makalah, kertas kerja, skripsi, tesis, dan disertasi (Arifin, 1998).

Suatu bentuk ketidakjujuran sering ditemukan saat seorang penulis baik ia seorang mahasiswa, peneliti, dosen, perawat maupun ilmuwan lainnya secara sadar maupun tidak mengabaikan penulisan sumber kepustakaan yang dikutip dalam tulisannya dengan benar. Bahkan ada suatu kondisi yang pernah ditemui penulis ketika seseorang dengan jelas mengakui karya orang lain sebagai karangan ilmiahnya atau mengakui tulisan yang dikerjakan bersama kelompok sebagai hasil karangan individualnya padahal bisa saja kontribusinya dalam tulisan tersebut sangan minimal atau tidak ada sama sekali.

Berbagai kasus plagiatisme khususnya di negara luar dapat berlanjut ke meja hijau. Bahkan pernah terjadi adanya tuntutan dari suatu penerbit pada seorang penulis yang dianggap melakukan plagiatisme hasil karya penulis itu sendiri karena menuliskan kembali tulisannya dalam bentuk lain tanpa ijin penerbit sebelumnya.

Hal inilah yang menjadi salah satu alasan yang melatarbelakangi penulis untuk mengingatkan kembali berbagai aspek etika dalam penulisan karya ilmiah khususnya keperawatan. Tujuannya adalah agar mutu karangan ilmiah keperawatan dapat terjaga dari berbagai aspek ketidakjujuran yang akan merusak nilai-nilai kebenaran karya ilmiah itu sendiri. 


\section{ETIKA PENULISAN DAN DAMPAKNYA}

"Etik (Yunani: ethos) berarti norma, nilai, dan kaidah moral yaitu ukuran bagi tingkah laku yang baik" (Tjokronegoro, 1989). Hal ini tentunya juga berkaitan dengan perilaku seorang ilmuwan dalam melaksanakan setiap aktifitasnya. Saat ini memang masih tidak mudah memberikan sanksi bagi berbagai bentuk pelanggaran etika penulisan yang tentunya hanya mengikat penulis secara moral. Walaupun undang-undang hak cipta telah mengatur hal ini secara legal, masih juga ditemui berbagai pelanggaran khususnya kasus plagiatisme yang lolos dari ketentuan hukum. Dapat juga ditemui karya ilmiah yang ditulis tanpa memperhatikan aspek etika penulisan, misalnya isi tulisan yang tidak sesuai dengan judul tulisan atau pembahasan tulisan yang terlalu dangkal sehingga tidak memenuhi kebutuhan pembacanya, sehingga perkembangan ilmu tersebut tidak diterima secara utuh.

Ketentuan etika tentunya tidak sekuat ketentuan hukum yang jelas sanksinya bila ketentuan hukum tersebut dilanggar. Walau demikian, seyogyanya setiap ilmuan memiliki kesadaran tinggi memenuhi aspek etika di dalam setiap aktifitasnya.

Etika penulisan berhubungan erat dengan etika penelitian karena seorang peneliti harus menuliskan hasil penelitian yang menyajikan kebenaran/ fakta tersebut dalam bentuk tulisan. Bila tidak, ia telah dapat dikatakan melanggar etika tersebut, karena tujuan dasar seseorang melakukan penelitian ialah menemukan kebenaran relatif tentang hukum alam dengan segala seluk beluknya demi meningkatkan kesejahteraan hidup orang banyak. Jadi, bila hasil penelitian tidak ditulis berarti apa yang telah dihasilkan tidak diketahui masyarakat luas dan tidak dapat dimanfaatkan orang lain (Oemijati, dkk, 1994).

Rifai (2001) secara tegas menyatakan bahwa "agaknya sudah perlu ditumbuhkan sikap bahwa hasil penelitian-terutama yang dananya dibebankan pada anggaran belanja negara, yang berarti diambil dari pajak yang dipungut dari rakyat- yang tidak diterbitkan harus dianggap sebagai tindak kriminal". Dengan kata lain suatu penelitian dapat dinyatakan belum selesai dilakukan bila peneliti belum menuliskannya dalam bentuk karangan ilmiah yang dipublikasikan. Kewajiban itu secara etika tentunya menuntut setiap peneliti harus aktif menulis menyajikan tulisan ilmiahnya yang tentunya harus sesuai dengan kaidah etika penulisan karangan ilmiah.

"Science is a search for truth" (Shaughnessy \& Jechmeister, 1994). Ketidakjujuran dalam menuliskan fakta berbentuk karya ilmiah dapat mencelakakan orang lain atau paling tidak ia telaah menipu dirinya sendiri. Akibatnya hasil yang diperolehnya tidak ada nilainya sama sekali (Oemijati, dkk, 1994). Oleh karena itu kejujuran sebagai salah satu sikap ilmuah seorang ilmuan juga perlu dimiliki dan ditanamkan oleh seorang penulis yang menyampaikan suatu kebenaran pada masyarakat luas.

\section{ASPEK ETIKA DALAM KOMPONEN KARANGAN ILMIAH}

Berbagai prinsip etik dasar itu perlu ditekankan di semua gaya penulisan. Prinsip etika ini diatur untuk mencapai dua tujuan yaitu memastikan ketepatan atau keutuhan ilmu pengetahuan dan melindungi hak kekayaan intelektual (APA, 2001). Hasil kekayaan inteklektual berbentuk karangan ilmiah ini juga perlu tetap dijaga dari ketidakjujuran dan juga bentuk pelanggaran etika lainnya.

Kode etik penulisan karangan ilmiah yang perlu diperhatikan dalam menyebarluaskan tulisan ilmiah telah banyak dikemukakan oleh berbagai pendahulu. Berikut ini akan diuraikan berbagai aspek etika seperti yang terangkum dalam APA, 2001; Oemijati, dkk, 1994; Rifai, 2001; Tjokronegoro, 1989. 


\section{Judul karangan:}

- judul perlu memberikan gambaran menyeluruh tentang isi karangan dan ditulis secara bernas (tidak terlalu luas, namun spesifik sesuai dengan hal yang sedang dibahas)

- judul tidak bersifat propaganda/ mempromosikan sesuatu (kegiatan, barang, atau orang)

- judul perlu dijaga dari adanya eksplorasi akan identitas koresponden (menjaga privasi responden)

Misalnya seorang peneliti yang menuliskan hasil penelitiannya pada suatu produk tertentu atau meneliti tentang aktifitas seks di luar nikah pada suatu populasi tertentu. Judul tulisan yang dibuat sebaiknya tidak menampilkan produk atau responden tersebut, seperti "Perbandingan perawatan luka dengan bethadine dan kemicitien"

\section{Penulis:}

- nama penulis sesuai dengan pembuat tulisan dan penulis perlu mengetahui isi karangannya secara detail

- editor, pimpinan instansi, atasan penulis tidak perlu dicantumkan sebagai penulis

- seseorang yang hanya membantu menelaah hasil penelitiannya, tidak perlu namanya dicantumkan sebagai penulis

- seseorang calon peneliti yang dalam penelitiannya harus melakukan penelitiannya dan berada di bawah bimbingan seorang senior, maka namanya harus ditampilkan dan jangan sampai dihilangkan; bahkan namanya itu dapat ditampilkan sebagai penulis utama, sedangkan pembimbingnya sebagai penulis kedua

- seseorang yang namanya tercantum dalam suatu publikasi harus mengatahui bahwa namanya tercantum dan turut bertanggung jawab terhadap isi tulisan

- urutan pencantuman nama penulis disesuaikan dengan besar-kecilnya kontribusi/ perannya dalan tulisan ilmiah tersebut bukan berdasarkan urutan abjad nama penulis
- penulis hanya akan mengajukan naskah yang dipersiapkan sesuai dengan format yang dibakukan dan dengan cermat akan mengikuti petunjuk yang digariskan penyunting. Hal ini akan mempermudah proses penyuntingan

- penulis berkewajiban tanggap terhadap usul dan saran penyunting sehingga segera mengembalikan naskah yang harus diperbaiki dan direvisinya agar tujuan memajukan ilmu dan teknologi dapat tercapai secepatnya

\section{Isi tulisan:}

- informasi dalam tulisan harus mudah dibaca dan dipahami; benar (tidak dimanipulasi dan tidak menyesatkan) baik teks, gambar, tabel, atau grafik; dan bermanfaaat. Isi tulisan yang menampilkan data palsu justru akan menyesatkan pembaca.

- perhatikan dan junjung tinggi kerahasiaan (privacy) data yang perlu dirahasiakan misalnya identitas responden atau data mentah yang akan menampilkan keburukan suatu populasi tertentu

- penggunaan informasi dari penulis lain harus dikutip dan ditulis secara benar dan tepat, objektif (tidak menambah/ mengurangi), sopan (tidak meremehkan) tepat (menggunakan sumber yang sesuai), dan jujur (tidak menipu diri sendiri atau bahkan mencelakakan orang lain), serta menghindari plagiatisme baik plagiat atas tulisannya sendiri maupun plagiat berdasarkan tulisan orang lain

- tulis semua bahan bacaan yang dikutip (bukan yang tidak) dalam daftar kepustakaan. Bahan bacaan yang dipilih hendaknya yang benar-benar bermanfaat dan relevan dengan penelitian yang dilakukan. Tidak perlu mencantumkan semua bahan yang dibaca dengan tujuan untuk memperlihatkan jumlah bahan bacaan yang sangat banyak itu.

\section{Publikasi tulisan:}

- tidak mempublikasikan (lisan dan tertulis) tulisan dalam bentuk yang sama untuk kedua kalinya tanpa ijin tertulis dari tempat publikasi yang pertama. Bila tulisan telah disampaikan pada tempat lain maka perlu diberikan 
penjelasan berupa catatan kaki bahwa hal tersebut telah disampaikan pada kegiatan/ tempat lain. Misalnya tulisan ini telah disampaikan pada simposium keperawatan ginjal hipertensi di Hotel Sahid pada 2 Juni 2001.

- tidak memecah tulisan dalam beberapa bagian sehingga menghilangkan keutuhan pembaca akan pemahaman hal tersebut.

\section{PENUTUP}

Keperawatan sebagai suatu profesi tidak terlepas dari tanggung gugat (akontabilitas) professional dalam setiap tindakannya, termasuk dalam kegiatan menulis. Akontabel dalam setiap kegiatan menulis perawat tersebut secara internal dikendalikan oleh etika penulisan seperti yang telah dijelaskan dalam tulisan ini. Aspek etika ini perlu disepakati dan dilaksanakan oleh setiap penulis karangan ilmiah. Hal ini diharapkan dapat lebih meningkatkan kualitas karangan ilmiah keperawatan. (INR).

* Hanny Handiyani, SKp., M.Kes.: Staf pengajar bagian DKKD FIK-UI

\section{KEPUSTAKAAN}

American Psychological Association (2001). Publication manual of the American Psychological Association. (fifth edition). Washington, DC: APA

Arifin, E.Z. (1998). Dasar-dasar penulisan karangan ilmiah. Jakarta: PT Gramedia Widiasarana Indonesia (Grasindo)

Oemijati, S., Setiabudy, R., \& Budijanto, A. (ed.). (1994). Pedoman etik penelitian kedokteran Indonesia. Jakarta: FKUI

Rifai, MA. (2001). Pegangan gaya penulisan, penyuntingan, dan penerbitan karya ilmiah Indonesia. Yogyakarta: Gadjah Mada University Press

Shaughnessy, JJ. \& Jechmeister, EB. (1994). Research methods in psychology. (third edition). New York: McGraw-Hill. Inc.

Tjokronegoro, A, Setiadji, V.S., Markam, S. (1989). Peranan editor dalam penerbitan buku dan majalah ilmiah. Jakarta: Balai penerbit FKUI 


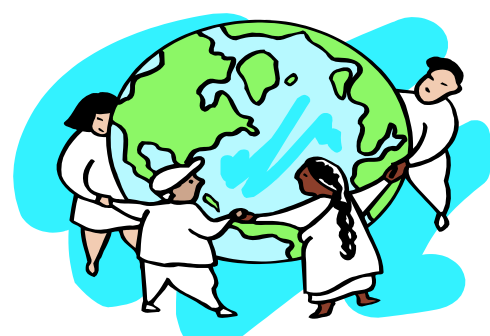

THE INTERNATIONAL WORKSHOP PSBH fOr NURSES 2003

\section{PELATIHAN INTERNATIONAL TREND TERKINI DALAM PENYELESAIAN MASALAH KESEHATAN}

Senin-Rabu, 13-15 Oktober 2003

FIK-UI, Salemba Raya 4 Jakarta, 10430

Fasilitator:

1. Dame Sheila (UK). 2. Pamela Hoyt (USA).

3. Fasilitator dari UI dan FIK UI

Biaya: Rp. 500.000,- (sebelum 1 Oktober 2003) atau

Rp. 600.000,- (setelah 1 Oktober 2003)

Tandai Kalender anda sekarang juga! Jangan sampai terlewatkan!

Kesempatan terbatas!!!

Informasi dan pendaftaran:

Sekretariat: Dwi Setyani Telp./Fax.: 0217864124

Terselenggara atas kerjasama:

FIK UI Dreyfus Healt Foundation, New York PUSKA UI 